\title{
Profil Populasi Sapi Pesisir Di Kabupaten Pesisir Selatan Sumatera Barat
}

\author{
Sarbaini $^{1}$, R. Angraini ${ }^{2}$, R. Suhati ${ }^{2}$, dan A. Husni ${ }^{2}$ \\ Jurusan Produksi Ternak Fakultas Peternakan Universitas Andalas, Padang
}

\begin{abstract}
The purpose of the present study was to estimate the population characteristics of the Pesisir cattle in Pesisir Selatan district of the West Sumatera province. Purposive sampling procedure was used to collect data from 484 farmers rearing about 1341 Pesisir cattle in Pesisir Selatan. The data were statistically analyzed descriptively. Results of the study showed that ratio of male to female was $1: 7$. The population was dominated by females with the age of more than 3 years $(35,72 \%)$, while the lowest $(0.89 \%)$ was the male at more than 3 years of age. The rate of calving, calving percentage, and percent of died were $24.09 \%, 49.85 \%$, and $1.98 \%$, respectively.
\end{abstract}

Key words: Pesisir cattle, population characteristics

\section{Pendahuluan}

Data dari Direktorat Jenderal Peternakan dalam sepuluh tahun terakhir menunjukkan bahwa sub sektor peternakan belum mampu memenuhi, terutama kebutuhan/ konsumsi daging dalam negeri. Sementara itu, seiring dengan semakin membaiknya kondisi kesejahteraan masyarakat, permintaan akan daging sapi dan susu cenderung meningkat. Produksi daging sapi dan kerbau pada tahun 1998 mencapai 398 ribu ton atau sebesar $31,7 \%$ dari total produksi daging sebesar 1,2 juta ton, sedangkan konsumsi daging sapi dan kerbau pada tahun yang sama mencapai 419 ribu ton, sehingga terdapat kekurangan sekitar 30 ribu ton. Untuk memenuhi kebutuhan dan kekurangan daging sapi tersebut, dengan terpaksa pemerintah mengimpor ternak sapi bakalan dan daging beku rata - rata per tahun mencapai 350 ribu ekor (Ditjennak, 2000 sitasi IPTEKDA LIPI, 2001).

Sumatera Barat memiliki wilayah seluas sekitar $42229,64 \mathrm{~km}^{2}$ dengan populasi sapi potong tercatat sebanyak 501356 ekor (BPS Sumatera Barat, 2001) termasuk sapi lokal yang dikenal dengan sapi Pesisir. Kabupaten Pesisir Selatan memiliki luas wilayah $5 \quad 749,89 \mathrm{~km}^{2}$ dengan topografi bergunung dan berbukit bukit dengan ketinggian $0-1000 \mathrm{~m}$ dari permukaan laut. Populasi sapi di Kabupaten Pesisir Selatan pada tahun 2001 tercatat sejumlah 96443 ekor (BPS-Sumatera Barat, 2001), sekitar $95 \%$ dari populasi ini adalah sapi Pesisir.

Menurut Schlegel dan Muller (1810) yang diacu dalam Merkens (1926) mengemukakan bahwa di pantai barat daya Sumatera yakni di Padang dan dataran tinggi sekitarnya terdapat sapi dengan penampilan yang berbeda dari sapi yang ada di pulau Jawa. Sapi - sapi tersebut jauh lebih kecil dan pendek badannya, kakikakinya lebih ramping, dan keseluruhan bangun tubuhnya tampak lebih indah dibanding sapi di Jawa. Sapi jantan jarang memiliki punuk yang sebenarnya (berpunuk kecil). Baik yang jantan maupun yang betina berwarna kuning kemerahan, kecuali di sekitar pantat dan bagian bawah 
kakinya biasanya berwarna lebih muda dan keputih - putihan. Selanjutnya Leurink (1923) yang juga diacu dalam Merkens (1926) mengemukakan bahwa di Kota Padang dan dataran tinggi sekitarnya terdapat sapi dengan ciri - ciri antara lain; sapi pejantan memiliki kepala yang pendek, bertanduk pendek dan mengarah ke luar, lehernya lebar, kokoh dan pendek. Punuknya cukup berkembang, daerah pinggulnya pendek dan oval. Bagian depan badannya lebih ringan dibanding bagian belakangnya. Kakinya relatif pendek, pada betina kepalanya lebih panjang dan kecil, pundak dan dadanya kurang berkembang, selangkangnya miring kebelakang, pendek dan kecil. Warnanya coklat muda sampai coklat tua, atau sampai hitam. Sekitar mata, mulut dan sebelah dalam kaki - kakinya, perut bagian bawah berwarna lebih muda. Tinggi pundak pada yang jantan antara 1 - 1,26 m (rata - rata 1,15 m), dan pada yang betina sekitar $1,05 \mathrm{~m}$.

Sapi Pesisir merupakan ternak piaraan masyarakat yang menyebar secara merata di Kabupaten Pesisir Selatan. Di daerah - daerah tertentu yang tidak memiliki areal persawahan, masyarakat memelihara ternak ini secara ekstensif tradisional, yaitu dengan membiarkan sapi tersebut lepas pada siang dan malam hari tanpa atau dengan sedikit sekali campur tangan pemiliknya. Semenjak lama, sapi Pesisir memegang peranan penting dalam pengadaan ternak potong sehari - hari dan sebagai hewan qurban pada hari raya Idul Adha untuk kota Padang dan bahkan sampai ke provinsi tetangga, seperti Riau.

Dengan bentuk dan ukurannya yang khas, sapi Pesisir telah dimasukkan dalam salah satu sumberdaya genetik ternak lokal Indonesia (Utoyo et al., 1996), disertai dengan nilai ekonomisnya yang cukup besar baik bagi masyarakat maupun pemerintah daerah Pesisir Selatan maka perlu dilakukan upaya - upaya untuk memelihara keberadaan (konservasi) dan sekaligus meningkatkan produktivitasnya.

Profil populasi suatu bangsa ternak sangat diperlukan sebagai dasar bagi konservasi dan pengembangan bangsa ternak tersebut. Jumlah jantan betina biasanya digunakan untuk mengetahui ukuran efektif suatu populasi, sedangkan komposisi umur diperlukan untuk mengetahui produktivitas dari populasi tersebut.

Berdasarkan pada beberapa hal yang disampaikan di atas, maka penelitian ini dilakukan dengan tujuan untuk mengetahui profil populasi sapi Pesisir di Kabupaten Pesisir Selatan sebagai sentra populasi sapi Pesisir di Sumatera Barat.

\section{Materi Dan Metoda}

\section{Materi}

Penelitian ini dilakukan terhadap 1341 ekor sapi Pesisir yang dipelihara oleh 484 KK (kepala keluarga) peternak sampel, yang menyebar pada tiga Kecamatan di Kabupaten Pesisir Selatan.

\section{Metoda}

\section{Pengambilan sampel}

Penelitian ini dilakukan dengan pengamatan langsung pada kelompok ternak milik setiap KK sampel. KK sampel diambil menggunakan purpossive sampling mulai dari tingkat Kecamatan, Nagari, dan KK peternak. 
Tiga Kecamatan sampel: (a) Koto XI Tarusan, (b) Batang Kapas, dan (c) Ranah Pesisir dipilih mewakili wilayah mulai dari ujung bagian utara, bagian tengah, sampai bagian ujung selatan Kabupaten Pesisir Selatan, masing - masing Kecamatan sampel, diambil sampel Nagari sebanyak $50-100 \%$ dari total nagari pada kecamatan tersebut. Setiap nagari sampel didata jumlah KK peternaknya dan kemudian sampel KK peternak per nagari diambil secara acak sebesar $10 \%$ - $20 \%$ dari total KK peternak. Berdasarkan pada metoda pengambilan sampel ini, diperoleh sebaran sampel penelitian sebagaimana disajikan pada Tabel 1.

\section{Peubah yang diamati}

Peubah yang diamati pada penelitian ini adalah peubah yang dapat memberi gambaran tentang populasi, yaitu: (a) jumlah ternak menurut jenis kelamin, (b) jumlah ternak menurut tingkat umur, (c) tingkat kematian, dan (d) tingkat kelahiran.

Tingkat umur ternak yang diamati pada penelitian, terdiri dari: (a) $0,5-1$, (b) $\geq 1-2$, (c) $>2-3$, (d) dan (e) $>3$ tahun. Penentuan umur dilakukan berdasarkan pada per- tukaran gigi seri dari gigi susu menjadi gigi permanen menurut Santosa (2003).

\section{Analisis data}

Data hasil pengamatan dianalisis secara deskriptif dengan menghitung rata - rata, simpangan baku, dan persentase.

\section{Hasil Dan Pembahasan}

\section{Komposisi umur dan jenis kelamin dalam populasi sapi Pesisir}

Komposisi populasi sapi Pesisir secara lengkap disajikan pada Tabel 2. Dari Tabel 2 dinyatakan bahwa umur sapi Pesisir yang paling banyak dipelihara masyarakat dalam populasi ini $(35,72 \%)$ adalah betina yang berumur $>3$ tahun, dan sebaliknya yang paling sedikit $(0,89 \%)$ adalah jantan umur $>3$ tahun. Hasil penelitian ini memperlihatkan bahwa peternak cenderung mempertahankan betina untuk jangka waktu lama karena peternak lebih bertujuan untuk menghasilkan anak (pembibitan). Sebaliknya, peternak memelihara jantan hanya dalam waktu yang relatif singkat (kebanyakan sampai umur 2 tahun).

Tabel 1. Sebaran Sampel Penelitian (Kk) Dan Jumlah Ternak Menurut Kecamatan dan Nagari di Kabupaten Pesisir Selatan

\begin{tabular}{lllcc}
\hline No & Kecamatan & \multicolumn{1}{c}{ Nagari } & $\begin{array}{c}\text { Jumlah KK } \\
\text { peternak }\end{array}$ & KK sampel \\
\hline 1. & Koto XI Tarusan & Batu Hampar & 120 & 47 \\
& & Duku & 132 & 26 \\
& & Nanggalo & 166 & 33 \\
& & Barung-barung belantai & 70 & 14 \\
\hline 2. & Batang Kapas & IV Koto Mudiak & 634 & 63 \\
& & IV Koto Hilir & 1215 & 122 \\
& & Taluak & 337 & 34 \\
\hline 3. & Ranah Pesisir & Palangai & 931 & 93 \\
& & Sungai Tunu & 544 & 54 \\
\hline
\end{tabular}


Tabel 2. Sebaran Populasi Sapi Pesisir di Kabupaten Pesisir Selatan

\begin{tabular}{|c|c|c|c|c|c|c|c|c|}
\hline \multirow{2}{*}{ No } & \multirow{2}{*}{ Kecamatan } & \multirow{2}{*}{$\begin{array}{c}\text { Jenis } \\
\text { Kelamin }\end{array}$} & \multicolumn{4}{|c|}{ Tingkat umur (th) } & \multirow{2}{*}{ Sub Total } & \multirow{2}{*}{ Total } \\
\hline & & & $0,5-1$ & $>1-2$ & $>2-3$ & $>3$ & & \\
\hline \multirow[t]{2}{*}{1.} & \multirow{2}{*}{$\begin{array}{l}\text { Koto XI } \\
\text { Tarusan }\end{array}$} & $\begin{array}{l}\text { Jantan: } \\
\text { Ekor (\%) }\end{array}$ & $55(54,4)$ & $37(48,0)$ & $3(4,7)$ & $3(2,1)$ & $98(25,3)$ & \multirow{2}{*}{387} \\
\hline & & $\begin{array}{l}\text { Betina: } \\
\text { Ekor (\%) }\end{array}$ & $46(45,6)$ & $40(52,0)$ & $61(95,3)$ & $142(97.9)$ & $289(74,7)$ & \\
\hline \multirow[t]{3}{*}{2.} & \multirow{3}{*}{$\begin{array}{l}\text { Batang } \\
\text { Kapas }\end{array}$} & Jantan: & & & & & & \multirow{3}{*}{484} \\
\hline & & Ekor (\%) & $52(39,6)$ & $52(49,5)$ & $31(42,5)$ & $5(2,8)$ & $140(28,9)$ & \\
\hline & & Ekor (\%) & $79(60,4)$ & $53(50,5)$ & $42(57,5)$ & $170(97,2)$ & 344 (71.1) & \\
\hline \multirow[t]{5}{*}{3.} & \multirow{3}{*}{ Ranah Pesisir } & Jantan: & & & & & & \multirow{3}{*}{470} \\
\hline & & $\begin{array}{l}\text { Ekor (\%) } \\
\text { Betina: }\end{array}$ & $54(59,3)$ & $25(51,0)$ & $55(34,6)$ & $4(2,3)$ & $138(29,4)$ & \\
\hline & & Ekor (\%) & $37(40,7)$ & $24(49,0)$ & $104(65,4)$ & $167(97,7)$ & $332(70,6)$ & \\
\hline & \multirow[t]{2}{*}{ Total } & $\begin{array}{l}\text { Jantan: } \\
\text { Ekor (\%) } \\
\text { Detine. }\end{array}$ & $161(49,8)$ & $114(49,4)$ & $89(30,1)$ & $12(2,4)$ & 376 & \multirow{2}{*}{1341} \\
\hline & & Ekor (\%) & $162(50,2)$ & $117(50,6)$ & $207(69,9)$ & $479(97,6)$ & 965 & \\
\hline
\end{tabular}

Dari Tabel 2 dapat dinyatakan bahwa pada umur $>1-2$ tahun jumlah jantan hampir sama banyaknya dengan yang betina ( 275 vs 279 ekor), namun pada umur lebih dari 2 tahun jumlah sapi jantan jauh lebih sedikit dibanding yang betina (101 vs 686 ekor).

Dari kondisi ini muncul pertanyaan: kemana saja sapi jantan setelah berumur dua tahun? Dari hasil pengamatan dan informasi dari masyarakat ternyata bahwa sapi jantan pada umumnya telah mulai dijual peternak pada umur 2 tahun. $\mathrm{Hal}$ ini dilakukan oleh peternak disebabkan, antara lain: (a) tingginya permintaan pedagang ternak, baik untuk dikirim ke rumah potong maupun untuk hewan qurban. (b) perkiraan nilai ekonomisnya tertinggi, (c) peternak tidak lagi membutuhkan sapi jantan yang lebih kuat dan lebih besar sebagai ternak pembajak karena telah tersedia banyak mesin bajak tangan, dan (d) tidak efisien untuk terus dipelihara.

Dari data di atas dapat juga dilihat bahwa jumlah sapi betina pada umur di atas 2 tahun jauh lebih banyak dibanding jantan. $\mathrm{Hal}$ ini mengindikasikan bahwa peternak di daerah ini lebih mengutamakan memelihara betina dengan alasan: (a) peternak lebih memilih perkembangbiakan atau pembibitan dibanding penggemukan, dan (b) pembibitan lebih menguntungkan dibanding penggemukan.

Imbangan jantan dan betina dewasa pada umur $>2$ tahun diperoleh sebesar $1: 7$. Imbangan ini berada di bawah kisaran normal sebagaimana yang dikemukakan oleh Saladin (1993) bahwa pada umur 3 tahun dengan sistem pasture mating satu ekor pejantan dapat mengawini 26 - 34 ekor betina. Imbangan jenis kelamin yang diperoleh ini mengindikasikan bahwa populasi sapi Pesisir ini sudah kekurangan jumlah betina dari yang seharusnya sehingga dapat mengakibatkan rendahnya tingkat kelahiran dan persentase melahirkan.

Rendahnya jumlah betina dalam populasi sapi Pesisir ini berarti telah terjadi pengurasan sapi betina yang cukup besar. Pengurasan sapi betina ini disebabkan oleh tingginya permintaan pedagang baik untuk dikirim ke rumah potong atau untuk hewan 
qurban yang diiringi oleh kurangnya pengawasan pengeluaran sapi betina oleh instansi terkait.

\section{Tingkat kelahiran populasi dan persentase melahirkan}

Tingkat kelahiran dalam populasi sapi Pesisir ini, diperkirakan dari jumlah individu yang berumur $0,5-1$ tahun dan total populasi dari tiga Kecamatan sampel, disajikan pada Tabel 2. Dengan perkiraan ini diperoleh tingkat kelahiran dalam populasi sapi Pesisir sebesar 24,09\%.

Dari Tabel 2 juga dapat diperkirakan persentase melahirkan (calving percentage) yang dihitung berdasarkan pada jumlah individu yang berumur $0,5-1$ tahun dibandingkan dengan jumlah betina produktif yang berumur $>2$ tahun. Dengan cara ini diperoleh perkiraan persentase melahirkan (calving percentage) dalam populasi sapi Pesisir sebesar 49,85\%. Angka ini diperoleh dengan perhitungan sebagai berikut:

- Jumlah individu ternak yang berumur $<1$ tahun (323 ekor)

- Jumlah betina umur $>2$ tahun (686 ekor)

- Jika asumsi tingkat kematian anak sampai umur $<1$ tahun adalah $6 \%$, maka jumlah anak saat lahir adalah $\{(6 / 100) \times$ $323\}+323$ atau 342 ekor

- Tingkat kelahiran (calving percentage) adalah $\frac{\text { jumlahanaklahir }}{\text { jumlahbetinadewasa }} \times 100 \%$ atau $=\frac{342}{686} \times 100 \%=49,85 \%$

Jika dihitung dari total sampel, tingkat kelahiran dalam populasi sapi Pesisir (24,09\%), sedikit lebih tinggi dibandingkan data Dinas Peternakan Tingkat I Sumatera Barat (2003) yang memperoleh angka kelahiran sebesar 20,98 \%. Dari angka persentase melahirkan sebesar $(49,85 \%)$ yang diperoleh pada penelitian ini, ternyata masih berada dalam kisaran normal menurut Martojo (1992), yaitu sebesar 40 - $80 \%$, namun lebih rendah dibandingkan Saladin (1993) yang mengemukakan bahwa untuk Indonesia, koefisien teknis persentase kelahiran ternak sapi potong adalah sekitar $65 \%$.

Rendahnya tingkat kelahiran dan persentase melahirkan sapi Pesisir ini dapat disebabkan, antara lain oleh:

a. Jumlah sapi betina yang relatif sedikit akibat semakin tingginya pemotongan betina, baik langsung ke rumah potong maupun untuk hewan qurban

b. Kualitas pakan rendah. $\mathrm{Hal}$ ini disebabkan karena ternak sapi Pesisir hanya mengkonsumsi rumput - rumput liar yang tumbuh di semak belukar, pinggir jalan, atau di kebun - kebun kelapa. Hijauan yang dikonsumsi oleh ternak ini pada umumnya berumur muda, memiliki kadar air tinggi dan kurang bahan kering. Disamping itu, peternak tidak memberikan pakan tambahan, baik berupa hijauan maupun konsentrat. Akibatnya, ternak kekurangan pasokan gizi utama, seperti protein dan mineral yang sangat dibutuhkan bagi kinerja reproduksi yang normal.

c. Walaupun proporsi jantan dewasa terhadap betina dewasa relatif besar, namun mungkin sebarannya kurang merata sehingga 
banyak betina birahi tidak sempat dikawini oleh pejantan.

d. Sistim perkawinan ternak di daerah ini pada umumnya masih dengan cara alamiah. Inseminasi buatan tidak dapat dilakukan secara massal karena peternak pada umumnya beralasan bahwa sapi Pesisir berukuran kecil sehingga jika dilakukan inseminasi buatan kemungkinan akan terjadi kesulitan melahirkan.

\section{Tingkat kematian}

Perkiraan tingkat kematian pada penelitian ini dihitung dari jumlah ternak yang mati pada satu tahun terakhir dibanding dengan total sampel. Dengan cara ini diperoleh tingkat kematian dalam populasi sapi Pesisir sebesar 1,98 \%. Kematian ini pada umumnya disebabkan oleh beberapa kejadian seperti diare, kembung, sakit ketuaan, atau kesulitan melahirkan. Dilihat dari penyebab kematian pada sapi Pesisir ini, ternyata tidak ditemukan kematian yang disebabkan oleh penyakit - penyakit menular.

Tingkat kematian pada penelitian ini lebih rendah dibandingkan Saladin (1993) yang mengemukakan bahwa angka kematian pada sapi berkisar pada $2 \%$ untuk yang dewasa dan $6 \%$ untuk anak. Rendahnya tingkat kematian dalam populasi sapi Pesisir ini dimungkinkan oleh tingginya daya tahan ternak terhadap beberapa jenis penyakit menular.

\section{Kesimpulan Dan Saran}

\section{Kesimpulan}

Dari penelitian ini dapat disimpulkan bahwa proporsi populasi sapi Pesisir betina di Kabupaten
Pesisir Selatan jauh lebih sedikit dari yang seharusnya, sehingga dapat mengakibatkan menurunnya laju pertumbuhan populasi ternak sapi tersebut. Jika hal semacam ini dibiarkan terus menerus, dapat mengakibatkan kepunahan pada populasi sapi ini.

\section{Saran}

Dari penelitian ini dapat disarankan kepada pemerintah daerah Kabupaten Pesisir Selatan atau instansi yang berwenang untuk mengawasi dan memperketat pengeluaran atau pemotongan sapi betina produktif.

\section{Daftar Pustaka}

BPS Sumatera Barat, 2001. Sumatera Barat Dalam Angka. Padang.

Dinas Peternakan Tingkat I Sumatera Barat. 2003. Laporan Tahunan Populasi Ternak Sapi Sumatera Barat, Padang.

IPTEKDA LIPI. 2001. Lipi Ikut Berkiprah Dalam Bidang Pembibitan Sapi. Bulletin Komunikasi Info Iptek untuk Daerah. Vol 1 No.3. Jakarta.

Martojo, H. 1992. Peningkatan mutu genetik ternak. Direktorat Jenderal Pendidikan Tinggi, Pusat Antar Universitas Pangan dan Gizi Institut Pertanian Bogor, Bogor.

Merkens, J. 1926. De Paarden-En Runderteelt in NederlandschIndie. Departement Van Landbouw, Nijverheid en Handel. Landsdrukkerij Weltevreden.

Saladin, Rusjdi. 1993. Teknik Produksi Sapi Potong. Departemen Pendidikan dan Kebu- 
dayaan. Universitas Andalas, Padang.

Santosa. 2003. Tata Laksana

Pemeliharaan Ternak Sapi. Penebar Swadaya. Jakarta.

Utoyo, D.P., Djarsanto, and S.N. Nasution. 1996. Animal Genetic
Resources and Domestic Animal Diversity in Indonesia. Ministry of Agriculture, Directorate General of Livestock Services, Directorate of Livestock Breeding Development. Jakarta.

Alamat korespondensi: DR. Ir. Sarbaini, MSc

Dosen (Lektor Kepala) Genetika dan Pemuliaan Ternak pada Fakultas Peternakan Universitas Andalas.

Alamat rumah : J1. Thamrin No. 54, Padang 25162

Alamat kantor : Kampus Unand Limau Manis, Pauh, Padang, Telp. 0751-74208 Fax: 0751-71464, HP: 08126628212

Email: sarbaini.anwar@yahoo.com

Blog: http://www.sarbaini.multiply.com

Diterima: 3 September 2007, Disetujui: 20 September 2007 